\title{
Planlama Kapsamında Kentsel Risklerin Tespiti ve Derecelendirilmesine Yönelik İki Çalışma: Kocaeli Örneği*1
}

\author{
Nurseli Şanlı ${ }^{2}$ \\ ORCID: 0000-0003-4336-590X \\ Sibel Ecemiş Kılıç4 \\ ORCID: 0000-0003-3928-8462
}

\author{
Fatma Nur Varol ${ }^{3}$ \\ ORCID: 0000-0003-2405-0603 \\ Mercan Efe Güney ${ }^{5}$ \\ ORCID: 0000-0001-8498-4796
}

Öz

Literatürde ekosistemlerin sürdürülebilirliğinin să̆lanması hedefiyle ortaya çıkan dirençlilik kavramı, özellikle son 10 yılda geliştirilerek, pek çok farklı konu ve perspektifte ele alınmaya başlamıştır. Günümüz planlama yaklaşımları çoğunlukla sosyo-ekonomik odaklı olup, kentsel dirençlilik alanında afet risklerinin tanımlanmasından öteye geçememektedir. Oysaki kavram doğal kaynakların sürdürülebilirliğinin să̆lanması, afet ve benzeri riskler ile ekonomik, sosyal ve fiziksel bă̆lamda kentlerde yaşanan veya öngörülen sorunlarn çözülmesine, hafifletilmesine olanak tanıyabilmesi sebebiyle her ölçekteki planda değinilmesi gereken önemli bir konudur. Bu çalışmada üretilecek planlarda kentsel dirençliliği sağlamak ve artırmak adına risklerin tespiti ve seviyelerinin derecelendirilmesine yönelik uygulanabilir bir yöntem geliştirmek, geliştirilen yöntemin mekânsal planları yönlendirmekteki katkısını sunmak çalışmanın amacını oluşturmuştur. Geliştirilen yöntem farklı ölçek ve sinıra sahip iki plan olarak Kocaeli ili İzmit İlçesi Afet Müdahale Planı ve Kocaeli ili İzmit Körfezi Bütünleşik Kıyı Alanları Planı yapım aşamalarına entegre edilerek uygulanmıştır. Çalışma kapsamında geliştirilen yöntemin diğer planlara uygulanabilirliğinin ve mevcuttaki sorunlara yönelik çözüm önerilerinin gerçekleşebilirliği ile sürdürülebilirliğinin sağlanıp sağlanamayacağının tartışılması hedeflenmiştir.

Anahtar Kelimeler: Kentsel Dirençlilik, Kentsel Risk, Kocaeli, Kent Planlama, Afet, Kıyı Alanı

\footnotetext{
* Bu makale çalışması “5.Kent Araştırmaları Kongresi” nde bidiri olarak sunulmuştur.

${ }^{1}$ Makale Dokuz Eylül Üniversitesi, Mimarlık Fakültesi, Şehir ve Bölge Planlama Bölümü eğitim programında yer alan PLN 4122 Şehir Planlana Projesi VI kapsamında Nurseli Şanlı ve Fatma Nur Varol tarafından Prof. Dr. Sibel Ecemiş Kılıç ve Doç. Dr. Mercan Efe Güney danışmanlığında yapılan projelerinin verileri kullanılarak elde edilmiştir.

${ }^{2}$ Yüksek Lisans, Dokuz Eylül Üniversitesi, E-mail: nurselisanli8@gmail.com

${ }^{3}$ Yüksek Lisans, Dokuz Eylül Üniversitesi, E-mail: fatos48.03@gmail.com

${ }_{4}^{4}$ Prof. Dr., Dokuz Eylül Üniversitesi, E-mail: sibel.ecemis@deu.edu.tr

${ }^{5}$ Doç. Dr., Dokuz Eylül Üniversitesi, E-mail: mercan.efe@deu.edu.tr
}

idealkent @ C Kent Araştırmaları Dergisi (Journal of Urban Studies)

http://idealkentdergisi.com

Geliş Tarihi Received Date: 24.12.2020 Kabul Tarihi Accepted Date: 16.04.2021 


\title{
Two Studies for Identifying and Classifying Urban Risks in the Scope of Planning: The Case of Kocaeli ${ }^{6}$
}

\author{
Nurseli Şanl1 ${ }^{7}$ \\ ORCID: 0000-0003-4336-590X \\ Sibel Ecemiş Kılıç 9 \\ ORCID: 0000-0003-3928-8462
}

\author{
Fatma Nur Varol ${ }^{8}$ \\ ORCID: 0000-0003-2405-0603 \\ Mercan Efe Güney ${ }^{10}$ \\ ORCID: 0000-0001-8498-4796
}

\begin{abstract}
The concept of resilience, which emerged with the literature in the aim of ensuring the sustainability of ecosystems, especially in the last 10 years has been developed and has begun to be addressed many different topics and perspectives. Today's planning approaches are focused on socio-economic development and do not define the risks that may be required in the urban area beyond disasters. However, the concept is an important issue that should be considered in all scale plans. The aim of the study was to develop a viable method for identifying and evaluating risks in order to ensure urban resilience and increase their levels of plans to be produced, and developed the present method of directing spatial contribution plans. The developed method was implemented by integrating Izmit District Disaster Response Plan and Izmit Bay Integrated Coastal Areas Plan on the basis of Kocaeli Province into the construction stages as two plans with different scales and limits. It is aimed to discuss the applicability of the method developed within the scope of the study to other plans and, as a result, whether the realization and sustainability of the solution proposals for existing problems can be achieved.
\end{abstract}

Keywords: Urban Resilience, Urban Risk, Kocaeli, Urban Planning, Disaster, Coastal Area

\footnotetext{
${ }^{6}$ The article was written by Nurseli Şanlı and Fatma Nur Varol under the guidance of Prof. Dr. Sibel Ecemis Kilic and Assoc. Prof. Mercan Efe Güney within the scope of the data produced by PLN 4122 Urban Planning Project VI, which is given in the Department of Urban and Regional Planning at The Faculty of Architecture of Dokuz Eylül University.

${ }^{7}$ Master, Dokuz Eylül University, E-mail: nurselisanli8@gmail.com

${ }^{8}$ Master, Dokuz Eylül University, E-mail: fatos48.03@gmail.com

${ }^{9}$ Prof. Dr., Dokuz Eylül University, E-mail: sibel.ecemis@deu.edu.tr

${ }^{10}$ Assoc. Prof. Dr., Dokuz Eylül University, E-mail: mercan.efe@deu.edu.tr

idealkent @ Kent Araştırmaları Dergisi (Journal of Urban Studies)

http://idealkentdergisi.com

Geliş Tarihi Received Date: 24.12.2021 Kabul Tarihi Accepted Date: 16.04.2021
} 


\section{Giriş}

Dirençlilik kavramı ilk olarak ekosistemlerin sürdürülebilirliğini sağlamak hedefiyle, bu sistemlerin geçirdiği krizler ve şoklar sırasında yaşanan değişim ve değişimin yarattığı etki ile başa çıkma yollarını tanımlamaya yönelik kullanılmıştır (Holling, 1973 s. 17; Lebel vd., 2006). Bir başka deyişle dirençlilik, bir sistemin değişikliklerle başa çıabilme kapasitesi anlamına gelir (Töyli, Lorentz, Ojala, Wieland ve Wallenburg, 2013). Kentsel dirençlilik ise, bir kentin veya bir kent parçasının zaman içinde yaşanan ekonomik, sosyal, fiziksel veya politik değişimlere kendini hazırlaması, yanıt vermesi ve tehditlere karşı en az zarar ile uyum sağlayarak direnmesi anlamına gelmektedir. Bir sistem bütünü olarak ele alınması gereken kentin, olası şok ve krizlere karşı geliştireceği dirençliliği tanımlayabilmek için söz konusu sorunların iyi anlaşılması ve doğru tanımlanması gerekmektedir.

Dirençlilik kavramının ayrılmaz bir parçası olan ve farklı alanlarda kullanılan "risk" kavramı, olası bir tehlike sonucu ortaya çıkabilecek zararın/kayıpların bir ölçüsüdür. Dolayısıyla risk, zarar görebilecek veya kaybedilebilecek bir değeri temsil etmektedir. Eğer zarar görecek herhangi bir değer yoksa geriye sadece tehlikenin kendisi kalmakta ve riskten söz edilememektedir (Balamir, 2007).

Herhangi bir tehlike karşısında zarar görebilecek demografik, ekonomik, kültürel ve çevresel değerlerin yoğun olarak bulunduğu kentsel alanlarda risk kavramından sıkça söz edilmektedir. Kentlerde, tehlikelerden bahsedilirken, aynı zamanda bu tehlikelerin etkisini artırıc veya başlı başına risk oluşturan planlama veya yönetim kaynaklı unsurlar da bulunmaktadır. Kentlerin gelecekte meydana gelebilecek kayıplardan kaçınabilmesi için risk ve kırılganlığın anlaşılması gerekmektedir. Riski doğru anlamak ve yorumlamak için kentin doğal, mekânsal, ekonomik ve sosyal özellikleri bağlamında riski belirleyen unsurların ne olduğu ortaya konmalıdır.

Bu bağlamda zarar görebilir unsurlar belirlenmeli; nelerin, ne ölçüde ve hangi etkilerden zarar görebileceği saptanmalıdır. Risk ve kırılganlık üzerine yapılan çalışmalarda Tehlike (Hazard), Maruziyet (exposure), Savunmasızlık veya Kırılganlık (Vulnerability), Hassaslık (Suscepbility), Başa Çıkma Kapasitesi veya Esneklik (Coping Capacity) gibi kavramlarla alt sinıflandırmalar oluşturulmuştur (Balica vd., 2009; Balica vd., 2012; De Leon, 2006; İstanbul Sismik Rismin Azaltılması ve Acil Durum Hazırlık Projesi [İSMEP], 2014). Bu sınıflandırmalara ilişkin kavramlar aşağıda açıklanmıştır (Bu konuda daha ayrıntılı bilgi için bkz. İSMEP, 2014). 
"Tehlike, can ve mal kayıplarına neden olmak ile birlikte, topluma, doğal çevreye, doğal, tarihi ve kültürel kaynaklara zarar verme potansiyeli olan doğa, teknoloji ve insan kaynaklı olay ve olaylar zinciridir". Maruziyet (exposure) kavramı, tehlike meydana geldiğinde etkilenecek insan ve kıymetlerin miktarı ve sayısı olarak belirtilmektedir. Savunmasızlık (vulnereability) ise, tehlike gerçekleştikten sonra toplumun uğrayacağı olası yıkım ve zararların derecesi olup toplumun baş edebilme kapasitesiyle ters orantılıdır (Kadığlu, 2011). Savunmasızlı̆̆ın bir unsuru olarak Hasar Görebilirlik olası bir tehlike karşısında belirli bir öğenin olası riski artırıcı özelliklerini içermektedir. Yönetebilirlik, olası risklere karşı mevcut yasal ve yönetsel yapı tarafından ele alınan hazırlık aşaması, planlama aşaması gibi zarar azaltıcı değişkenlere bağlı olarak afet durumunda etkilenen toplumun, zarar ve kayıplarını en aza indirgeme ve onunla baş edebilme seviyesi ve kapasitesi olarak tanımlanmaktadır.

Dolayısıyla risk, tehlike, maruziyet ve hassasiyet ile doğru orantıll; başa çıkabilme kapasitesi, esneklik veya yönetilebilirlikle ters orantılı bir fonksiyondur ve bu kavramların bir bileşkesidir. Olası tehlike ve risklere karşı zarar azaltma amacıyla alınan tedbirler ve afet öncesinde risklerin belirlenmesi ve yönetilmesi konusundaki çalışmalar, özellikle ağır kayıplar verilen afetler sonucunda elde edilen tecrübelerle önemini artırmaktadır.

Risk azaltım çalışmaları temel olarak sırasıyla; risk tanımının yapılması, risk tespiti, saptanan risklerin değerlendirilmesi ile azaltımına yönelik kararlar üretilmesi ve geliştirilmesi aşamalarından oluşmaktadır. Yapılan çalışmalarda risk, tehlike haritalarının oluşturulması, karşılaştırmalı risk analizleri ve nicel yöntemlerle hesaplanabilmektedir. Tehlike analizleri; fiziksel çevre kaynaklı, deprem, sel vb. doğal olayların oluşma sıklıkları, mekânsal dağılımlarının incelenmesidir. Karşılaştırmalı risk analizleri, risk konularını bağlamına göre sınıflandırma ve AHP (Analytic Hierarchy Process) gibi yöntemlerle öncelik belirleme yoluyla siralama yapılarak kaynakların uygun biçimde yönlendirilmesini sağlamaktadır (Hester ve Harrison, 1989). Niceliksel risk analizleri ise, riskin tanımından ortaya çıkan, maruz kalma, hassaslık, savunmasızlık, yönetilebilirlik, başa çıkabilme kapasitesi kavramlarını içeren formüllerin kullanılması yoluyla yürütülmektedir (Balica vd., 2009; Balica vd., 2012; De Leon, 2006). Risk tespitine ilişkin yöntem tercihi ve tanımı, risk çalışması yapılacak planın ölçeği, kapsamı ve çalışma alanının özelliklerine göre yapılmalıdır. 
Planlama disiplininde risklerin genellikle mekânsal planlar hiyerarşisinde yer alan planlarda, tehlike haritaları oluşturulması yoluyla tespit edildiği görülmektedir. Ancak analiz ve sentez aşamalarında oluşturulan jeolojik, morfolojik, depremsellik, eşik analizi gibi çalışmalar riskleri anlamada ve yorumlamada yetersiz kalmaktadır. Mekânsal planlarda jeolojik etütler ve afet tehlike haritaları ile geliştirilen strateji ve kararlar, olası riskleri olumlu veya olumsuz olarak etkileyebilecek hususları içermediğinden planların risk açısından dirençsiz olmasına sebep olmaktadır (Durgun, t.y.). Bu durum özel nitelikleri nedeniyle hassasiyet gerektiren doğal ve kültürel alanlara ilişkin hazırlanan koruma amaçlı imar planları açısından da geçerlidir. Bu planlarda da risklerin belirlenmesi aşaması, diğer planlarda olduğu gibi yüzeysel kalmakta ve sonuçta korunması ve yaşatılması gereken doğal/kültürel unsurlara ilişkin risk oluşturabilecek birçok unsur dikkate alınmamaktadır.

Ancak bu durum Türkiye'de kentlere yönelik olası risklerin ve tehlikelerin hiç dikkate alınmadığı anlamına da gelmemektedir. Kentlerin afetlere karşı dirençliliğini artırmaya yönelik Afet Müdahale Planı, Deprem Master Planı ve İklim Değişikliği Eylem Planı gibi planlar farklı kurumlarca, farklı ölçeklerde hazırlanmaktadır. Bu planlar mevcut tehlikelerin ve risklerin belirlenmesi, gerekli tedbirlerin alınması, müdahalelerin geliştirilmesi gibi önemli hususları içermektedir. Fakat burada da tehlike odaklı, kentsel alanda tehlikenin şiddetini artııcı unsurların göz ardı edildiği analizler ve plan kararlarıyla karşılaşılmaktadır. Buna ek olarak bu planlar, kentin gelişimini yönlendiren mekânsal planlar ile entegre edilememektedir. Dolayısıyla bu planlarda daha çok yönetim ve kurumlar arası koordinasyon üzerinde durulduğunu ve risk tespiti ve azaltımına yönelik mekânsal kararlar geliştirilmediğini söylemek mümkündür.

Dirençli kent, planlama bakımından yeterli, afet bilgisi ve farkındalığ1 oluşmuş, yaşanan afet sonrasında hemen normale dönebilecek, sektörlerin devamlılığının sağlandığı, risk, zarar azaltma ve müdahale çalışmalarının yürütüldüğü kenttir (Okay, 2018). Böyle bir kent için tehlike altında olan unsurların zarar görebilirliklerinin belirlenmesi gerekmektedir. Dirençlilik konusu özellikle stratejik düzeyde karar üreten farklı nitelikteki planlama çalışmalarına entegre edilebilecek özellikler taşımaktadır. Bununla birlikte uygulama ölçek, araç ve yöntemlerinin geliştirilmesi gereksinimi bulunmaktadır. Bu kapsamda geleneksel planlama analiz ve yöntemlerinden farklı yaklaşımlar içeren örnek çalışmaların çoğalması, konunun planlama sistemine entegrasyonunu kolaylaştıracaktır. 
Bu aşamada riskin tanımından ortaya çıkan niceliksel hesaplama yöntemleri kullanılarak risk ve kırılganlık durumunun saptanmasına örnek oluşturacak çalışmalara gereksinim vardır. Bu çalışmalar rasyonel sonuçlar ortaya koyacağından, kaynak kullanımını doğru yönlendirerek, planların dirençlilik kapsamında oluşturulmasını ve alınan kararların gerçekleşebilme ihtimalini artıracaktır. Aşağıda verilen çalışmaların dirençlilik konusunun planlama disiplinine entegrasyonu konusunda örnek oluşturacağ düşünülmektedir.

Örnek olarak ele alınan her iki çalışma için de Kocaeli ilinin seçim nedeni İstanbul, Bursa ve Ankara gibi metropollere yakın konumu, gelişmiş sektörel yapısı (lojistik, sanayi vb.) ile ülke ekonomisindeki rolüne karşın aynı zamanda deprem riskinin yüksek olduğu bir bölgede yer alması ve 1999 yılında yaşanmış olan İzmit Depreminin etkilerinin hâlâ hissedilmesidir. Aynı zamanda Kocaeli, Türkiye'nin 27 kıyı kentinden ve iki denize kıyısı olan 5 ilinden biridir. İzmit Körfezi 34 adet faal limanıla 2011-2020 yılları arasında Türkiye'nin en fazla yük hareketinin gerçekleştiği liman bölgesidir.

Dolayısıyla dirençliliğin Kocaeli ilinde planlama alanındaki uygulama biçimleri öne çıkmaktadır. Uygulama biçimlerinden biri de afet müdahale planıdır. Kentlerde yaşanabilecek afetlere hazırlıklı olmayı amaçlayan bir plan türü olarak Afet Müdahale Planı, ülkemizde afet risklerinin tespitinin yapıldığı en kapsamlı plandır. Bu nedenle risk tespitine yönelik yöntem Afet Müdahale Planı kapsamında ele alınmıştır.

Diğer yandan İzmit Körfezi barındırdığı askeri açıdan öncelikli alanlar, doğa koruma alanları, rekreatif amaçlı alanlar ve çeşitli kentsel kullanımlar nedeniyle risk açısından hassasiyetler taşımaktadır. Ekonomik, sosyal, siyasi ve politik açıdan değerli olup, doğal ve beşeri etkiler sebebiyle riske konu olan Kocaeli kıyı alanlarını kapsayan İzmit Körfezi Bütünleşik Kıyı Alanları Planının yapılma aşamasında risk tespiti ve değerlendirilme çalışmaları önem kazanmaktadır. Bu nedenle ikinci bir örnek olarak risk tespitine yönelik yöntem Bütünleşik Kıyı Alanları Planı kapsamında ele alınmıştır. Her iki çalışmada da dirençliliğin sağlanması için risklerin tespit edilmesi ve derecelendirilmesi gerekli görülmüştür.

Bu çalışmalar, risk ve kırılganlık tespitinde ayn zamanda birer veri seti kategorisi olarak kullanılan ve risk formülünün bileşenlerini oluşturan kavramların (tehlike, maruziyet, savunmasızlık veya kırılganlık, hassasiyet, başa çıkma kapasitesi veya esneklik) farklı veri setleri ile kullanımına örnek oluşturmaktadır. Dolayısıyla bu çalışmalarla riskin, uygulamanın kapsamı, ölçeği ve bağlamına göre farklı biçimlerde tanımlanabileceği ve her ölçekte plana entegre edilebileceği ortaya konulmaktadır. 
Sözü edilen entegrasyonun sağlanması açısından örnek oluşturabilecek dirençlilik eksenli olarak ele alınan farklı nitelikteki iki plan çalışması aşağıda yer almaktadır. Dirençlilik eksenli birer yöntem denemesi olan bu çalışmalardan ilki Afet Müdahale Planı, ikincisi ise Bütünleşik Kıyı Alanı Planıdır. Bu kapsamda Afet Müdahale Planı özellikle deprem riski açısından önem taşıyan İzmit kent merkezi örneği üzerinden; Bütünleşik Kıyı Alanı Planı ise bölgesi ve Ülke içindeki stratejik konumu nedeni ile Kocaeli Körfezi ve yakın çevresi örneği üzerinden risk derecelendirmesi yapılarak geliştirilmiştir.

Afet Müdahale Planı için İSMEP kapsamında verilen formül; Bütünleşik Kıyı Alanları Planında ise De Leon'un geliştirdiği Kıyı Kırılganlık Endeksi planlama disiplinine uyarlanarak risk derecelendirilmesi yapılmıştır. Her iki uygulamada da planlama çalışmalarında öncelikle alanın özelliğine ve çalışmanın amacına yönelik risk belirleme, derecelendirme çalışması yapılmasının önemi ortaya konmuştur.

\section{Dirençlilik Kapsamında Risk Tespitine Yönelik İki Farklı Niceliksel Uygulama}

Mevcut planlar incelendiğinde, analizlerin kentsel riskler belirlenmeden oluşturulduğu ve dolayısıyla planların riskler dâhil edilmeden yapıldığı görülmektedir. Bu durum plan kararlarının sürdürülebilirliğini ve uygulanabilirliğini tartışmalı hale getirmektedir. Bu nedenle karar aşamasından önce, gerçekleşebilecek riskler belirlenmelidir. Sonuçta, yapılacak müdahale çalışmaları daha gerçekçi ve verimli olacaktır.

İlk çalışma olan Kocaeli ili Afet Müdahale Planında; risk tespitinin yapılabilmesi için risk tanımından ortaya çıkan ve matematiksel olarak; "Risk= (Tehlike x Maruziyet x Savunmasızlık) / Başa Çıkabilme Kapasitesi" şeklinde (İSMEP, 2014) ifade edilen formül kullanılmıştır.

İkinci çalışma olan İzmit Körfezi Bütünleşik Kıyı Alanları Planında; risklerin saptanması için ise temel olarak İklim Değişikliği Eylem Planlarında kullanılan ve yukarıdaki formül ile benzerlik gösteren Kıyı Kırılganlık Endeksi (CVI-Coastal Vulnerability Index) olarak bilinen "Kırlganlik/Risk=(Maruziyet x Savunmasızlık) / Başa Çıkabilme Kapasitesi" (Balica vd., 2009; Balica vd., 2012; De Leon, 2006) formülü kullanılmıştır. Bu formülün uygulanması aşamasında veri setlerinin tek dil üzerinden değerlendirilmesini sağlamak amacıyla alanın özellikleri ve verilerin alansal büyüklüğü dikkate alınarak hücreleme yöntemi (200m x 200m) tercih edilmiştir. Hücre içerisine giren birden fazla kullanım alanının olması sorunu, baskın kullanım biçimlerinin seçilmesiyle çözülmüştür. 
Çalışma kapsamında tercih edilen her iki formül de riskin tanımı ve birleşenlerinden ortaya çıkmaktadır. Seçilen uygulama yöntemlerinde ele alınacak veriler, planların türü, ölçeği ve kapsamı düşünülerek çeşitlendirilmiş ve farklılaşmıştır. Her iki plan türüne yönelik olarak ele alınan risk ve veri sınıfları Tablo 1 ve Tablo 2' de verilmiştir.

Tablo 1. Afet Müdahale Planı Kapsamında Risk ve Veri Sınıfları

\begin{tabular}{|c|c|c|c|c|}
\hline Tehlike & & Maruziyet & Savunmasızlık & Başa Çıkabilme Kapasitesi \\
\hline $\begin{array}{l}\text { Deprem } \\
\text { Analizi }\end{array}$ & Tehlike & $\begin{array}{l}\text { Nüfus } \\
\text { Dağılımı }\end{array}$ & Eğim Durumu & $\begin{array}{l}\text { Toplanma Alanı m²Sağlama } \\
\text { Durumu }\end{array}$ \\
\hline $\begin{array}{l}\text { Heyelan } \\
\text { Analiz }\end{array}$ & Tehlike & Bina Sayısı & $\begin{array}{l}\text { Toplanma Alanı Hizmeti } \\
\text { Alma Durumu }\end{array}$ & $\begin{array}{l}\text { Kullanılabilirliği } \quad \text { Yüksek } \\
\text { Risk Azaltıcı Unsur Sayısı }\end{array}$ \\
\hline $\begin{array}{l}\text { Erozyon } \\
\text { Analizi }\end{array}$ & Tehlike & & $\begin{array}{l}\text { Tehlikeli Kullanıma } \\
\text { Yakınlık }\end{array}$ & \\
\hline
\end{tabular}

Tablo 2. Bütünleşik Kıyı Alanları Planında Kırılganlık ve Veri Sınıfları

\begin{tabular}{lll}
\hline Maruziyet & Savunmasızlık & Başa Çıkabilme Kapasitesi \\
\hline Turizm Çeşitliliği & Toprak Sınıfları & Ulaşım, Lojistik ve Sanayi Sektörü \\
\hline Eğim Durumu & Erozyon Durumu & Yerleşime Uygunluk \\
\hline Nüfus Yoğunluğu & Kıyıa Erişim & Arazi Kullanım Durumu \\
\hline Yapılaşma Baskısı & Riskli Alanlarda Yapılaşma & Planlı-Plansız Gelişme \\
\hline Kıyı Alanları Kirliliği & Toprak Kullanım Kabiliyeti & \\
\hline
\end{tabular}

Tablolar incelendiğinde benzer isim ile anılan veri sınıflarının altında farklı analizlerin ele alınabileceği görülmektedir. Bu durum planın ölçeği, niteliği ve kapsamına göre risk tespitinin farklı biçimlerde ele alınabileceğini; bu özelliğiyle risk kavramının temel olarak farklı nitelikteki planlara uygulanabileceğini ortaya koymaktadır.

\section{Afet Müdahale Planı ve Risk Tespiti}

Afetlere zamanında, hizlı ve etkili müdahale edebilmek, yerleşmelerin karşı karşıya olduğu riskleri önceden tespit ederek planlama, sakınma ve müdahale çalışmalarını etkili ve verimli bir biçimde gerçekleştirebilmek için risk belirleme çalışmalarının Afet Müdahale Planlarına entegre edilerek yürütülmesi önemlidir.

İlk aşamada alana ilişkin tehlikeler belirlenmiştir. Yapılan tehlike analizleri sonucunda deprem, diri fay, heyelan, aktif heyelan ve erozyon tehlikeleri derecelendirilmiş; bu dereceler toplaminda da formülde verilen tehlike ortaya konmuştur.

Kocaeli için en önemli afet riski depremdir. Son 60 yıl içerisinde doğal afetlerin yol açtı̆̆ yapısal hasar istatistikleri dikkate alındığında, hasarın 2/3'ünün deprem nedeniyle, $1 / 3$ 'ünün ise diğer afetler nedeniyle meydana 
geldiği görülmektedir. Mevcut tehlikelerin, mahallelerdeki dağılımının tespit edilebilmesi için, deprem tehlikesi ve diri fay hattının var olup olmaması, heyelan ve erozyon durumuna ilişkin verilen puanlar ile Tablo 3'de gösterilmiştir.

Tablo 3. Tehlike Derecesinin Belirlenmesinde Etkili Parametreler

\begin{tabular}{|c|c|c|}
\hline \multirow{5}{*}{ Deprem Tehlike Analizi } & 1. Derece Deprem Tehlikesi & 3 Puan \\
\hline & 2. Derece Deprem Tehlikesi & 2 Puan \\
\hline & 3. Derece Deprem Tehlikesi & 1 Puan \\
\hline & Diri Fay Var & 1 Puan \\
\hline & Diri Fay Yok & 0 Puan \\
\hline \multirow{7}{*}{ Heyelan Tehlike Analizi } & Çok Yüksek & 5 Puan \\
\hline & Yüksek & 4 Puan \\
\hline & Orta & 3 Puan \\
\hline & Seyrek & 2 Puan \\
\hline & Çok Seyrek & 1 Puan \\
\hline & Aktif Heyelan Var & 1 Puan \\
\hline & Aktif Heyelan Yok & 0 Puan \\
\hline \multirow{5}{*}{ Erozyon Tehlike Analizi } & 1. Derece Erozyon Tehlikesi & 5 Puan \\
\hline & 2. Derece Erozyon Tehlikesi & 4 Puan \\
\hline & 3. Derece Erozyon Tehlikesi & 3 Puan \\
\hline & 4. Derece Erozyon Tehlikesi & 2 Puan \\
\hline & Erozyon Tehlikesi Bulunmayan & 1 Puan \\
\hline
\end{tabular}

İkinci aşamada, maruziyetin tespitine ilişkin parametreler belirlenmiştir. Nüfusun fazla olduğu alanlar ile mevcut bina sayısının fazla olduğu alanlarda, meydana gelebilecek tehlikelere maruz kalacak insan ve bina sayısı artacağından, olası mal ve can kayıpları da artacaktır. Bu da mevcut riski etkilemektedir. Maruziyet derecesi, hasar görebilir nüfus ve bina dereceleri toplamından oluşmaktadır. Nüfus ve bina analizlerine ilişkin puanlama Tablo $4^{\prime}$ de verilmiştir.

Tablo 4. Maruziyet Derecesini Belirleyen Parametreler

\begin{tabular}{|c|c|c|}
\hline & 0-5000 kişi & 1 Puan \\
\hline \multirow{3}{*}{ Nüfus Analizi } & 5001-10000 kişi & 2 Puan \\
\hline & 10001-15000 kişi & 3 Puan \\
\hline & 15001-25000 kişi & 4 Puan \\
\hline \multirow{4}{*}{ Bina Analizi } & $100-400$ bina & 1 Puan \\
\hline & 401-600 bina & 2 Puan \\
\hline & 601-1000 bina & 3 Puan \\
\hline & $1000+$ bina & 4 Puan \\
\hline
\end{tabular}

Üçüncü aşamada, savunmasızlığın tespitine ilişkin parametreler belirlenmiştir. Çalışma alanında savunmasızlığı etkileyen parametreler olarak eğim, toplanma alanları ve tehlikeli kullanımlara yakınlık saptanmıştır. Bu kapsamda eğim oranlarına göre derecelendirilerek puanlanmıştır. Toplanma 
alanları hizmeti alma/almama durumunun belirlenebilmesi için 500 erişilebilirlik mesafesi dikkate alınarak mevcuttaki toplanma alanlarına network analizi uygulanmış ve hizmet almayan yerleşimler belirlenmiştir. Mahalle sınırları içerisinde toplanma alanı hizmeti almayan yerleşim yerinin var olup olmaması puanlanmıştır. Savunmasızlığın bir unsuru olarak hasar görebilirlik kavramı kapsamında ise; Kocaeli Afet Müdahale Planı'na göre riskli olarak kabul edilen kimya ve petrokimya tesislerine yakınlık ele alınmış ve 500 metre olarak kabul edilmiştir. Eğim, toplanma alanları ve kimya ve petrokimya tesislerine yakınlı unsurlarına ilişkin puanlama Tablo 5'de verilmiştir.

Tablo 5. Savunmasızlık Derecesini Belirleyen Parametreler

\begin{tabular}{|c|c|c|}
\hline \multirow{7}{*}{ Eğim Analizi } & $\% 0-\% 10$ & 1 Puan \\
\hline & $\% 11-\% 20$ & 2 Puan \\
\hline & $\% 21-\% 30$ & 3 Puan \\
\hline & $\% 31-\% 40$ & 4 Puan \\
\hline & $\% 41-\% 50$ & 5 Puan \\
\hline & $\% 51-\% 60$ & 6 Puan \\
\hline & $\% 61+$ & 7 Puan \\
\hline \multirow{2}{*}{$\begin{array}{l}\text { Toplanma Alanı } \\
\text { Hizmeti Alma } \\
\text { Durumu }\end{array}$} & Toplanma Alanı Hizmeti Almayan Yerleşim Yeri Var & 1 Puan \\
\hline & Toplanma Alanı Hizmeti Almayan Yerleşim Yeri Yok & 0 Puan \\
\hline \multirow{2}{*}{$\begin{array}{l}\text { Tehlikeli Kulla- } \\
\text { nıma Yakınlık }\end{array}$} & Kimya Fabrikasına Yakın & 1 Puan \\
\hline & Kimya Fabrikasına Yakın Değil & 0 Puan \\
\hline
\end{tabular}

Yönetebilirlik, zarar azaltma tedbiri derecesi olarak ele alınmış ve başa çıkabilme kapasitesi ismiyle ifade edilmiştir. Bu kapsamda belirlenen tedbirlerin (toplanma alanı, geçici barınma alanı, hastane olarak kullanılacak alan ve alternatif hasta bakım alanı) kişi/m2'ye uygunluğu ve kullanılabilirliğinin düşük veya yüksek olup olmadığı saptanmıştır. Başa çıabilme kapasitesi de $\mathrm{m} 2$ 'ye uygunluk derecesi ve kullanılabilirliği yüksek risk azaltıcı unsur toplamından oluşmaktadır.

Tablo 6. Başa Çıkabilme Kapasitesini Belirleyen Parametreler

\begin{tabular}{lll}
\hline Toplanma Alanı m² & Toplanma Alanı 1.5 Kişi/ $\mathrm{m}^{2} \mathrm{yi}$ Sağlayan Mahalle & 2 puan \\
\cline { 2 - 3 } Sağlama Durumu & Toplanma Alanı 1.5 Kişi/ $\mathrm{m}^{2}$ yi Sağlayamayan Mahalle & 1 puan \\
\hline Kullanılabilirliği Yüksek Risk Azaltıı Unsur Sayısı & \\
\hline
\end{tabular}

Elde edilen sonuçların formülde uygulanması ile 45 mahalle için risk değerleri bulunmuş ve Tablo 7'de belirtilmiştir. Tüm sonuçlar gruplandırılarak Şekil 1'de verilen haritada gösterilmiştir. 
Tablo 7. Mahallelerin Risk Değerlendirmesi

\begin{tabular}{|c|c|c|c|c|c|c|}
\hline $\begin{array}{l}\text { Mahalle } \\
\text { No }\end{array}$ & Mahalle & Tehlike & Maruziyet & Savunmasızlık & $\begin{array}{l}\text { Başa Çıkabilme } \\
\text { Kapasitesi }\end{array}$ & Risk \\
\hline 1 & Tavşantepe & 4 & 7 & 4 & 1 & 112 \\
\hline 2 & Gündoğdu & 7 & 5 & 3 & 1 & 105 \\
\hline 3 & 28 Haziran & 4 & 6 & 4 & 1 & 96 \\
\hline 4 & Turgut & 4 & 6 & 4 & 1 & 96 \\
\hline 5 & İzmit Fatih & 8 & 3 & 4 & 1 & 96 \\
\hline 6 & Serdar & 6 & 7 & 6 & 3 & 84 \\
\hline 7 & Yeşilova & 6 & 7 & 2 & 1 & 84 \\
\hline 8 & Cedit & 3 & 6 & 4 & 1 & 72 \\
\hline 9 & Tepeköy & 6 & 6 & 6 & 3 & 72 \\
\hline 10 & Doğan & 6 & 4 & 3 & 1 & 72 \\
\hline 11 & Topçular & 8 & 5 & 3 & 2 & 60 \\
\hline 12 & Fevzi Çakmak & 5 & 3 & 4 & 1 & 60 \\
\hline 13 & Tüysüzler & 6 & 3 & 3 & 1 & 54 \\
\hline 14 & Gültepe & 6 & 3 & 3 & 1 & 54 \\
\hline 15 & Yeni & 6 & 6 & 4 & 3 & 48 \\
\hline 16 & Alikahya C. & 5 & 3 & 3 & 1 & 45 \\
\hline 17 & Bekirdere & 5 & 6 & 3 & 2 & 45 \\
\hline 18 & Yenidoğan & 7 & 6 & 4 & 4 & 42 \\
\hline 19 & Şirintepe & 5 & 4 & 4 & 2 & 40 \\
\hline 20 & Erenler & 4 & 7 & 4 & 3 & 37 \\
\hline 21 & Cumhuriyet & 6 & 3 & 2 & 1 & 36 \\
\hline 22 & Terzi Bayırı & 3 & 3 & 4 & 1 & 36 \\
\hline 23 & Zabitan & 4 & 2 & 4 & 1 & 32 \\
\hline 24 & Hatipköy & 5 & 2 & 3 & 1 & 30 \\
\hline 25 & Akarca & 5 & 2 & 3 & 1 & 30 \\
\hline 26 & Kuruçeşme & 7 & 4 & 4 & 4 & 28 \\
\hline 27 & Malta & 9 & 4 & 3 & 4 & 27 \\
\hline 28 & Karabaş & 5 & 5 & 2 & 2 & 25 \\
\hline 29 & Kocatepe & 5 & 3 & 3 & 2 & 23 \\
\hline 30 & M. Ali Paşa & 5 & 7 & 2 & 3 & 23 \\
\hline 31 & Orhan & 7 & 3 & 2 & 2 & 21 \\
\hline 32 & Ayazma & 10 & 3 & 4 & 6 & 20 \\
\hline 33 & Yenişehir & 5 & 8 & 1 & 2 & 20 \\
\hline 34 & Kemalpaşa & 5 & 2 & 2 & 1 & 20 \\
\hline 35 & Hacıhızır & 3 & 3 & 4 & 2 & 18 \\
\hline 36 & Veliahmet & 3 & 3 & 4 & 2 & 18 \\
\hline 37 & Yahya Kaptan & 9 & 7 & 2 & 7 & 18 \\
\hline 38 & Hacihasan & 3 & 2 & 3 & 1 & 18 \\
\hline 39 & Kadıköy & 4 & 7 & 1 & 3 & 12 \\
\hline 40 & Akçakoca & 3 & 2 & 5 & 3 & 10 \\
\hline 41 & Çukurbağ & 3 & 3 & 2 & 2 & 9 \\
\hline 42 & Kozluk & 5 & 5 & 1 & 4 & 6 \\
\hline 43 & Körfez & 5 & 5 & 1 & 4 & 6 \\
\hline 44 & Ömerağa & 5 & 2 & 1 & 2 & 5 \\
\hline 45 & Tepecik & 6 & 2 & 1 & 4 & 3 \\
\hline
\end{tabular}




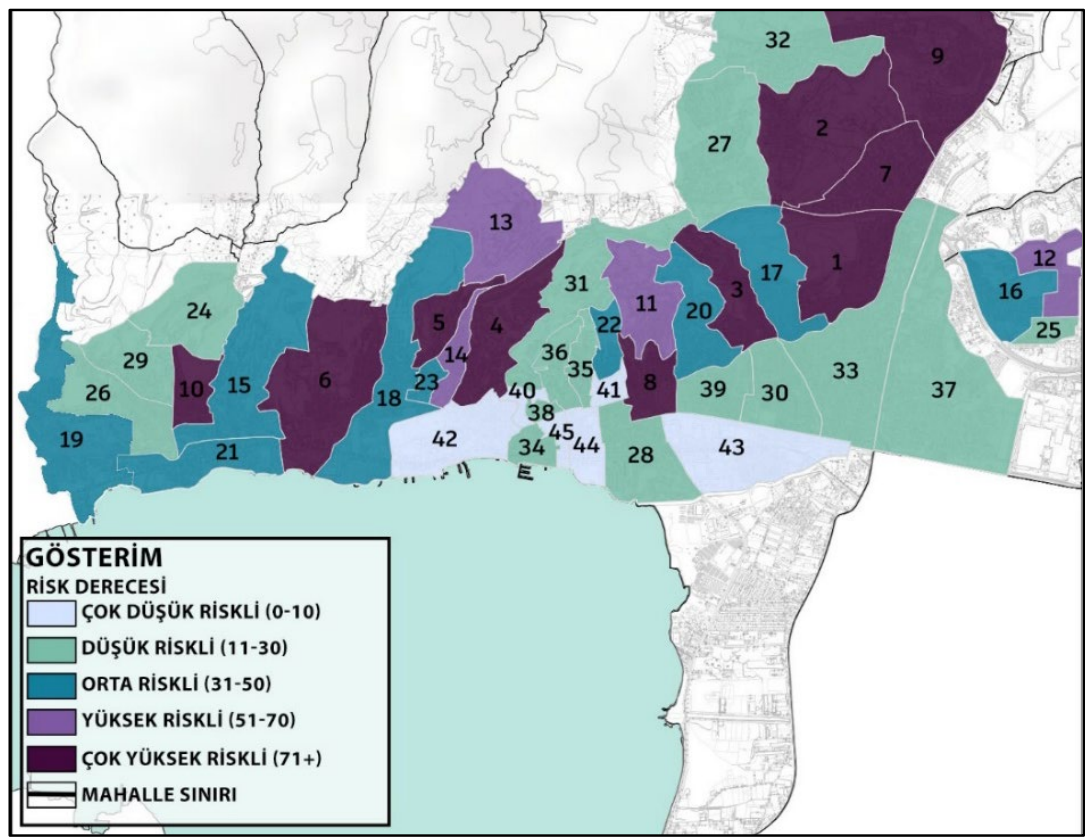

Şekil 1. Kocaeli İli İzmit İlçesi Risk Değerlendirmesi

\section{Bütünleşik Kıyı Alanları Planı ve Risk Tespiti}

Çevre ve Şehircilik Bakanlığı, Mekânsal Planlama Genel Müdürlüğü'nce belirtildiği gibi “Kıyı alanları, zengin doğal kaynak potansiyeli ve biyo-çeşitlilik barındıran, toplum için önemli ekonomik fırsatlar sunan, gelişme baskısı altında olan duyarlı alanlardır". Kentsel unsurların birçoğu bu kısıtlı ve yenilenemez doğal alanlarda yer seçmek istemektedir. Bu durum kıyı alanlarının hem doğal hem de beşeri etkiler sebebiyle yüksek bir baskı ve riske konu olan kırılgan alanlar olmasına sebep olmaktadır. Korunması gereken yenilenemez bir doğal kaynak olarak kıyı alanlarına ilişkin risk tespiti çalışmaları, kıyı planları ile entegre edilmesi gereken önemli bir çalışmadır.

Çalışma kapsamında edinilen veriler, kıyı alanlarına olan etkilerine göre risk derecelendirilmesi yöntemiyle ele alınmıştır. Kullanılan veriler Kocaeli Büyükşehir Belediyesi, Kocaeli Liman Başkanlığı, İstanbul ve Marmara, Ege, Akdeniz, Karadeniz (İMEAK) Deniz Ticaret Odası İstanbul ve Kocaeli Şubesi, Kocaeli Ticaret Odası, Kocaeli Sanayi Odası, Kocaeli Ulaşım Park A.Ş. Genel Müdürlüğü, Kültür ve Turizm Bakanlığı, Kocaeli Büyükşehir Belediyesi İmar ve Şehircilik Daire Başkanlığı, Kocaeli İli İl Gıda Tarım Ve Hayvancılık Müdürlüğü, Kocaeli Valiliği, Kocaeli Büyük Şehir Belediyesi Kentsel Dönüşüm ve Gelişim Şube Müdürlüğü, Kocaeli AFAD İl Müdürlüğü, Çevre Koruma 
ve Kontrol Dairesi Başkanlığı ve Deniz ve Kıyı Hizmetleri Şube Müdürlüğ̈̈'nden yerinde veya görüşme sonucu alınmıştır. Sınıflar halinde irdelenen veriler kıyıya olan etkilerine göre 5 dereceli olarak ele alınmıştır.

İlk aşamada alanda maruziyetin tespitine ilişkin parametreler belirlenmiştir. Maruziyet derecesi, turizm çeşitliliği, eğim durumu, kıyı alanları kirliliği, nüfus yoğunluğu, yapılaşma baskısı ve kıyı alanları kirliliği toplamından oluşmaktadır. Bu analizlere ilişkin puanlama Tablo 8'de verilmiştir.

Tablo 8. Maruziyet Derecesini Belirleyen Parametreler

\begin{tabular}{|c|c|c|}
\hline \multirow[t]{5}{*}{ Turizm Çeşitliliği } & Turizm Alanı Ve Çeşidi İçermeyen Alan & 5 puan \\
\hline & 1 Farklı Turizm Çeşidi İçeren Alan & 4 puan \\
\hline & 2 Farklı Turizm Çeşidi İçeren Alan & 3 puan \\
\hline & 3 Farklı Turizm Çeşidi İçeren Alan & 2 puan \\
\hline & 4 Farklı Turizm Çeşidi İçeren Alan & 1 puan \\
\hline \multirow[t]{5}{*}{ Eğim Durumu } & $\% 30+$ & 5 puan \\
\hline & $\% 0-\% 10$ & 4 puan \\
\hline & $\% 20-\% 30$ & 3 puan \\
\hline & $\% 15-\% 20$ & 2 puan \\
\hline & $\% 10-\% 15$ & 1 puan \\
\hline \multirow[t]{5}{*}{ Nüfus Yoğunluğu } & $136-299$ & 5 puan \\
\hline & $100-136$ & 4 puan \\
\hline & $56-100$ & 3 puan \\
\hline & $31-56$ & 2 puan \\
\hline & $0-31$ & 1 puan \\
\hline \multirow[t]{5}{*}{ Yapılaşma Baskısı } & Mutlak Tarım Arazisinde Yapılaşma & 5 puan \\
\hline & Marjinal Tarım ve Özel Ürün Arazisinde Yapılaşma & 4 puan \\
\hline & Dikili Tarım Arazisinde Yapılaşma & 3 puan \\
\hline & Çayır Ve Mera Alanlarında Yapılaşma & 2 puan \\
\hline & Orman Alanlarında Yapılaşma & 1 puan \\
\hline \multirow{3}{*}{$\begin{array}{l}\text { Kıyı Alanları } \\
\text { Kirliliği }\end{array}$} & 1. Derece Kıyı Kirliliği Görülen Alan & 5 puan \\
\hline & 2. Derece Kıyı Kirliliği Görülen Alan & 3 puan \\
\hline & 3. Derece Kıyı Kirliliği Görülen Alan & 1 puan \\
\hline
\end{tabular}

İkinci aşamada, savunmasızlı̆̆ın tespitine ilişkin parametreler belirlenmiştir. Çalışma alanında savunmasızlı̆̆ı etkileyen parametreler olarak toprak sınıfları, erozyon durumu, kıyıya erişim, riskli alanlarda yapılaşma ve toprak kullanım kabiliyeti saptanmıştır. Her bir analiz derecelendirilerek puanlanmış olup, bu puanlama Tablo 9'da verilmiştir. 
Tablo 9. Savunmasızlık Derecesini Belirleyen Parametreler

\begin{tabular}{|c|c|c|}
\hline \multirow{5}{*}{$\begin{array}{l}\text { Toprak Kullanım } \\
\text { Kabiliyeti }\end{array}$} & I. Sınıf Tarım Toprağı & 5 puan \\
\hline & II. Sınıf Tarım Toprağı & 4 puan \\
\hline & III. Sınıf Tarım Toprağı & 3 puan \\
\hline & IV. Sınıf Tarım Toprağı & 2 puan \\
\hline & V. Sınıf Tarım Toprağ1 & 1 puan \\
\hline \multirow{5}{*}{ Erozyon Durumu } & 1. Derece Erozyon Riskli Alan & 5 puan \\
\hline & 2. Derece Erozyon Riskli Alan & 4 puan \\
\hline & 3. Derece Erozyon Riskli Alan & 3 puan \\
\hline & 4. Derece Erozyon Riskli Alan & 2 puan \\
\hline & Erozyon Riskli Bulunmayan Alan & 1 puan \\
\hline \multirow{3}{*}{$\begin{array}{l}\text { Kıyıya Erişim (Herkes } \\
\text { İçin Kullanım Alanı } \\
\text { Olarak Kıyı) }\end{array}$} & Zor (Kıyıya Geçiş Kısıtlı, Özel Kullanımlar Yoğun) & 5 puan \\
\hline & $\begin{array}{l}\text { Orta (Kıyı Alanlarına Ulaşım Kolay, Özel Mülkiyet Yo- } \\
\text { ğunluklu ) }\end{array}$ & 3 puan \\
\hline & $\begin{array}{l}\text { Kolay (Kıyı Alanına Erişim Kolay, Kamusal Ve Yarı Ka- } \\
\text { musal Alanlar Yoğunluklu) }\end{array}$ & 1 puan \\
\hline \multirow{5}{*}{$\begin{array}{l}\text { Riskli Alanlarda } \\
\text { Yapılaşma }\end{array}$} & $\begin{array}{l}\text { Afete Maruz Kalan Alanlarda Yapılaşma (Deprem, Sel, } \\
\text { Heyelan) }\end{array}$ & 5 puan \\
\hline & Jeolojik Açıdan Riskli Alanlarda Yapılaşma & 4 puan \\
\hline & Yerleşime Uygun Olmayan Alanlarda Yapılaşma & 3 puan \\
\hline & Özel Etüd Gerekli Alanlarda Yapılaşma & 2 puan \\
\hline & Yerleşime Uygun Olan Alanlarda Yapılaşma & 1 puan \\
\hline \multirow{5}{*}{ Toprak Sinıfları } & Mutlak Tarım Arazisi & 5 puan \\
\hline & Marjinal Tarım ve Özel Ürün Arazisi & 4 puan \\
\hline & Dikili Tarım Arazisi & 3 puan \\
\hline & Orman Çayır Ve Mera Alanları & 2 puan \\
\hline & Doğal- Yarı Doğal ve Su Alanları & 1 puan \\
\hline
\end{tabular}

Üçüncü aşamada, başa çıkabilme kapasitesi, ulaşım, lojistik ve sanayi sektörü, yerleşime uygunluk, arazi kullanım durumu ve planlı-plansız gelime ile saptanmıştır. Bu parametrelere ilişkin puanlama Tablo 10'da verilmiştir.

Tablo 10. Başa Çıkabilme Kapasitesini Belirleyen Parametreler

\begin{tabular}{|c|c|c|}
\hline \multirow{5}{*}{$\begin{array}{l}\text { Ulaşım, } \\
\text { Lojistik Ve } \\
\text { Sanayi }\end{array}$} & 2 Farklı Sektör Alanı İçerme & 5 puan \\
\hline & 3 Farklı Sektör Alanı İçerme & 4 puan \\
\hline & 4 Farklı Sektör Alanı İçerme & 3 puan \\
\hline & 5 Farklı Sektör Alanı İçerme & 2 puan \\
\hline & 6 Farklı Sektör Alanı İçerme & 1 puan \\
\hline \multirow{5}{*}{$\begin{array}{l}\text { Yerleşime } \\
\text { Uygunluk }\end{array}$} & Afete Maruz Kalan Alan (Deprem, Sel, Heyelan) & 5 puan \\
\hline & Jeolojik Açıdan Riskli Alan & 4 puan \\
\hline & Yerleşime Uygun Olmayan Alan & 3 puan \\
\hline & Özel Etüt Gerekli Alan & 2 puan \\
\hline & Yerleşime Uygun Olan Alan & 1 puan \\
\hline \multirow{3}{*}{$\begin{array}{l}\text { Arazi } \\
\text { Kullanim } \\
\text { Durumu }\end{array}$} & $\begin{array}{l}\text { Şehirleşme, Endüstri, Ticaret Ve Ulaşım, Kültürel Tesisler, Plaj, Ku- } \\
\text { mul }\end{array}$ & 5 puan \\
\hline & Tarım Alanları, Madencilik, İnşaat & 4 puan \\
\hline & Kentsel Yeşil Alan, Bataklık & 3 puan \\
\hline
\end{tabular}




\begin{tabular}{lll}
\hline & Bitkisel Alan, Orman & 2 puan \\
\cline { 2 - 3 } & Su Kütleleleri, Su Yatakları & 1 puan \\
\hline \multirow{4}{*}{$\begin{array}{l}\text { Planlı- Plansız } \\
\text { Gelişme }\end{array}$} & Planı Olmayan Alanlar & 5 puan \\
\cline { 2 - 3 } & Planı İptal Olan Alanlar & 4 puan \\
\cline { 2 - 3 } & Planı Hazırlanmakta Olan Alanlar & 3 puan \\
\cline { 2 - 3 } & Planlı Alanlar & 2 puan \\
\hline
\end{tabular}

Elde edilen sonuçların formülde uygulanması ile Kıyı Alanında belirlenen her bir hücre için risk değerleri bulunmuştur. Bu formülün sonucu elde edilen Kıyı Kırılganlık Endeksi değerlerinin açıklanmasını kolaylaştırmak için normalizasyon formülü kullanılarak;

[Normalizasyon= (Kırılganlık Endeksi-Minimum Kırılganlık Endeksi Değeri) / (Maksimum Kırlganlık Endeksi-Minimum Kirnlganlık Endeksi)]

0 ile 1 değer aralığında dağılımı sağlanmıştır (Görmüş ve Ayat, 2020). Elde edilen değer, 5 seviye ile derecelendirilmiştir. Bu sayede çalışma alanındaki düşük ve yüksek riskli alanlar, nedenleri ile tespit edilmiştir. Elde edilen sonuçlar Şekil 2'de verilen haritada gösterilmiştir.

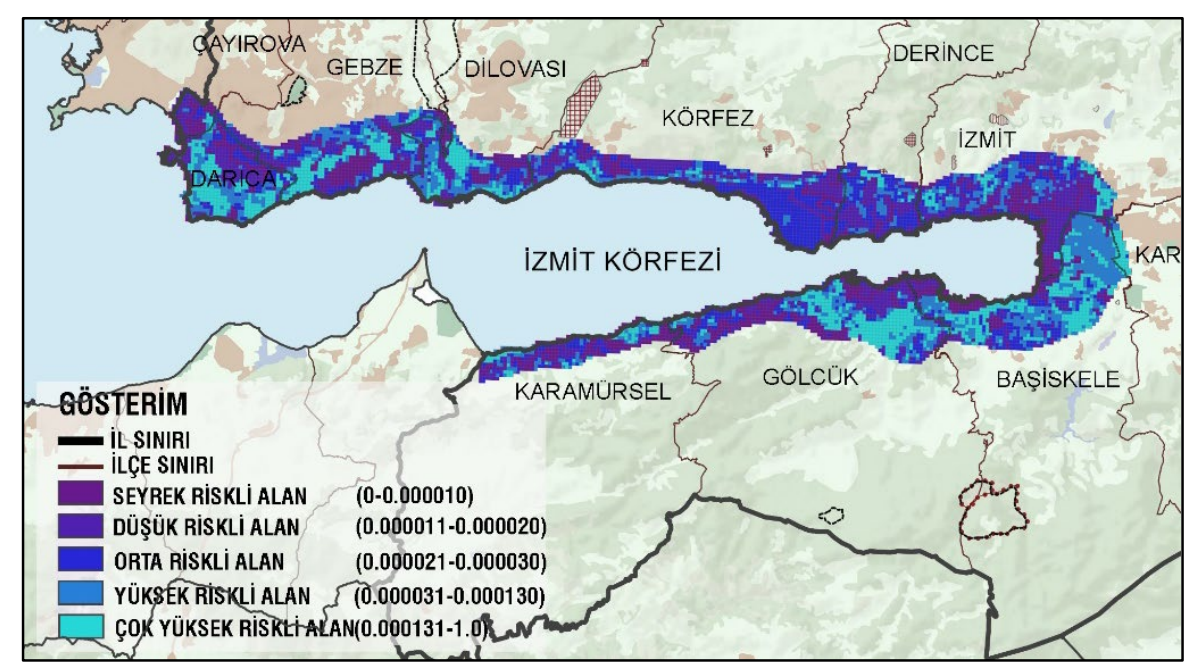

Şekil 2. Kocaeli İli Kıyı ve Kıyı Etkileşim Alanına İlişkin Risk Değerlendirmesi

\section{İki Farklı Nicel Risk Tespiti Çalışmasının Planlara Katkısı}

İki farklı nicel risk tespiti çalışması sonuçlarıyla ilgili planlar değerlendirilmiştir. Bu planların ölçek ve kapsamlarına göre riskleri/kırılganlığı ne ölçüde 
dikkate aldığı ve ürettikleri kararların dirençliliği sağlayıp sağlamayacağı konusunda değerlendirmeler yapılmıştır. Nicel risk tespit uygulamalarının planlara ne şekilde katkı sunacağı ortaya konulmuştur.

\section{Kocaeli İli, İzmit İlçesi Afet Müdahale Planının Çalışma Kapsamında Incelenmesi}

Kocaeli İli Afet Müdahale Planı, afet ve acil durumlarda görev alacak destek çözüm ortaklarıyla yapılan değerlendirmeler sonucunda Kocaeli Afet ve Acil Durum İ Müdürlüğü (AFAD) tarafından hazırlanmış ve Kocaeli Valisi başkanlığında İl Afet ve Acil Durum Koordinasyon Kurulu tarafından Temmuz 2017 yılında onaylanarak yürürlüğe girmiş ve 2020 yılında plan revizyonu gerçekleştirilmiştir. Mevcut plan, çalışma kapsamında risk tespitine ilişkin geliştirilen yöntemle elde edilen sonuçlara göre değerlendirilmiştir.

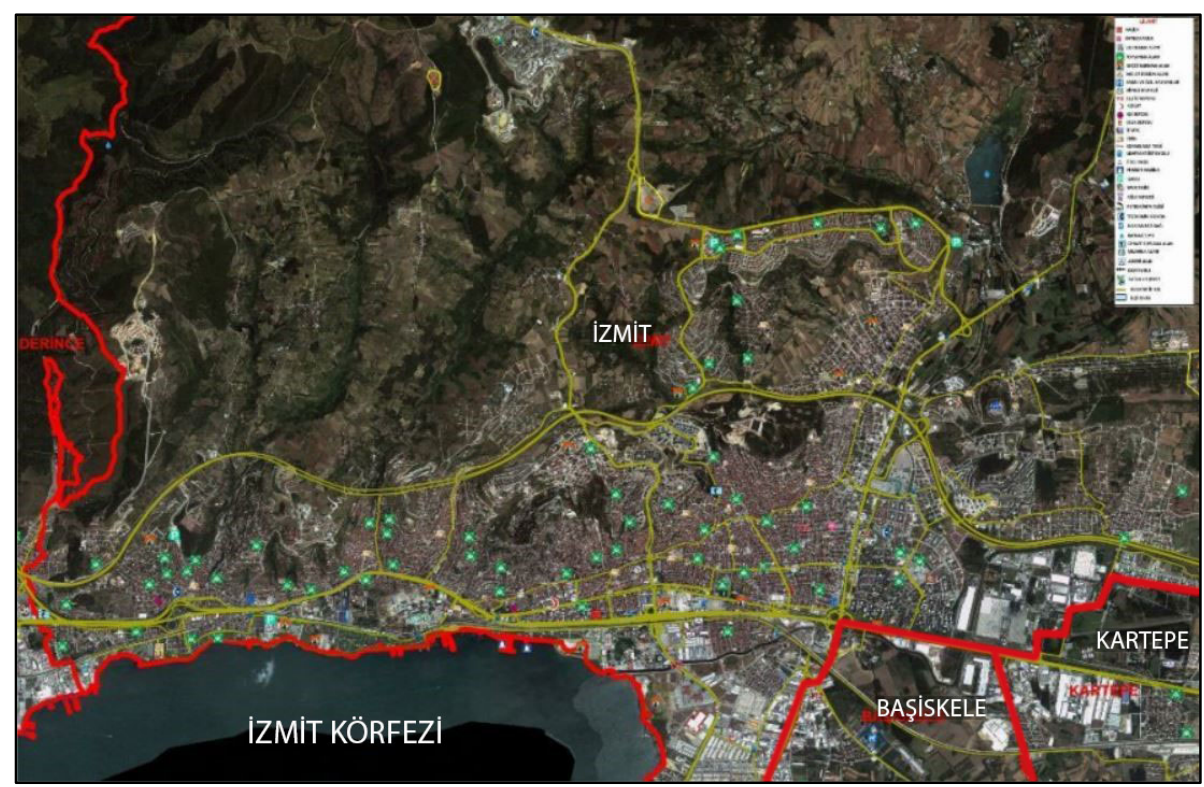

Şekil 3. Kocaeli İli Afet Müdahale Planı (Kaynak: AFAD, 2020. T.C. Kocaeli Valiliği, il Afet ve Acil Durum Müdürlüğü, yerinde alınan veriden düzenlenmiştir.)

Çalışma sonucunda, mevcuttaki durumu anlamak için sadece gerçekleşebilecek tehlikelere bakmanın yetmeyeceği; alanın riskini hesaplayıp buna göre kararlar almanın daha gerçekçi sonuçlara ulaştıracağı ortaya çıkmıştır. Örneğin Tablo 7'de mahallere göre elde edilen risk değerlendirmesine göre elde edilebilecek sonuçlara ilişkin örnekler aşağıda verilmiştir: 
- 1 No'lu Tavşantepe Mahallesi'ne afet müdahale planı kararı getirilmemiştir. Fakat yapılan risk belirleme çalışmasında Tavşantepe Mahallesinin maruziyet ve savunmasızlığı yüksek olduğu için alandaki en yüksek riskli mahalle olduğu saptanmıştır.

- 8 No'lu Cedit Mahallesi'nin tehlike derecesi çok düşük, maruziyet ve savunmasızlığı yüksektir. Mevcut planda, alanda bir adet toplanma alanı bulunmaktadır. Fakat bu toplanma alanına bakıldığında kullanılabilirliğinin düşük olduğu tespit edilmiştir ve bu durumun, plan kararının zarar azaltıcı etkisini ortadan kaldırdığı görülmektedir. Böylece Cedit Mahallesi de çok yüksek riskli alan olarak karşımıza çıkmaktadır.

- 32 No'lu tehlike derecesi en yüksek mahalle olan Ayazma Mahallesi'nin risk derecesinin de yüksek olması beklenirken, buraya verilen uygun plan kararları sonucunda risk derecesi beklenenin altında çıkmıştır.

Bu da tehlike ne kadar yüksek olursa olsun, zarar azaltma tedbiriyle, riskin azaltılabileceğini ve böylece olası can ve mal kayıplarının engellenebileceğini göstermektedir. Sonuçta, doğru zarar azaltma tedbirlerinin yerinde uygulanabilmesi için risk değerlerinin bilinmesi gerekliliği ortaya konulmuştur.

\section{İzmit Körfezi Bütünleşik Kıyı Alanları Planı'nın Çalışma Kapsamında} Incelenmesi

İzmit Körfezi (Kocaeli-Yalova) 1/50.000 ölçekli Bütünleşik Kıyı Alanları Planı, 05.06.2015 tarih ve 9573 sayılı Bakanlık Olur'u ile kesinleşmiş ve 1 No'lu Cumhurbaşkanlığı Kararnamesi'nin 102. maddesi uyarınca 30.06.2020 tarihinde plan değişikliği yapılarak onaylanmıştır. Mevcut plan ve plan raporu çalışma kapsamında risk tespitine ilişkin geliştirilen yöntemle elde edilen sonuçlara göre değerlendirilmiştir. 


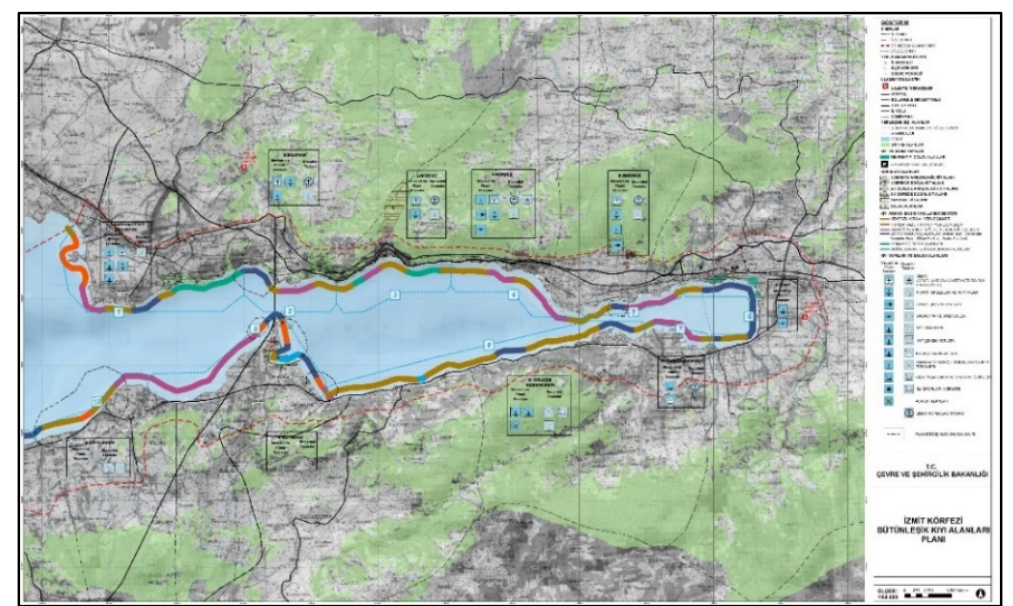

Şekil 4. İzmit Körfezi (Kocaeli-Yalova) Bütünleşik Kıyı Alanları Planı (Kaynak: Mekânsal Planlama Genel Müdürlüğü, t.y.)

Yürürlükte olan İzmit Körfezi Bütünleşik Kıyı Alanları Planında, risklere ilişkin değerlendirme, taşkın, heyelan ve deprem afetleri üzerinden genel bir perspektifle üretilmiştir. Ancak geliştirilen stratejiler "afet etkilerinden korunması" şeklinde ifade edilen yüzeysel bir içeriğe sahiptir. Planda geliştirilen önerilerin ve önemli kıyı yapılarının, kente yaratacağı etki irdelenmediğinden çeşitli alanlarda risk artışı ihtimali de bulunmaktadır.

Çalışma sonucunda, mevcuttaki durumu anlamak için alanın riskini hesaplayıp buna göre kararlar almanın daha gerçekçi sonuçlara ulaştıracağı ortaya çıkmıştır. Elde edilen risk değerlendirmesine göre elde edilebilecek sonuçlara ilişkin örnekler aşağıda verilmiştir:

- Şekil 5'de görüldüğü gibi Körfez ilçesinin Hereke bölgesi çok yüksek ve orta riskli seviyededir. Dik kıyı özelliğiyle kıyı erozyon tehlikesi göze çarpmaktadır. Planda Hereke-Körfez bölgesinde rekreatif amaçlı dolgu alanları önerilirken kıyı koruma yapılarına ilişkin herhangi bir öneri getirilmemiştir (Şekil 6). Bu durum mevcuttaki yüksek riski daha da artıracak niteliktedir. 


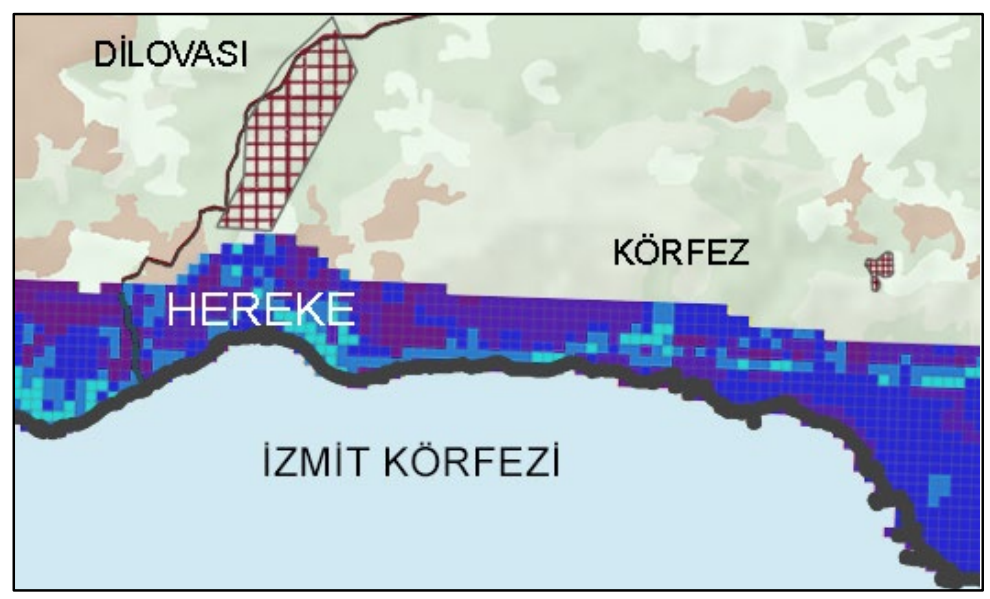

Şekil 5. Hereke Bölgesi Risk Derecelendirmesi

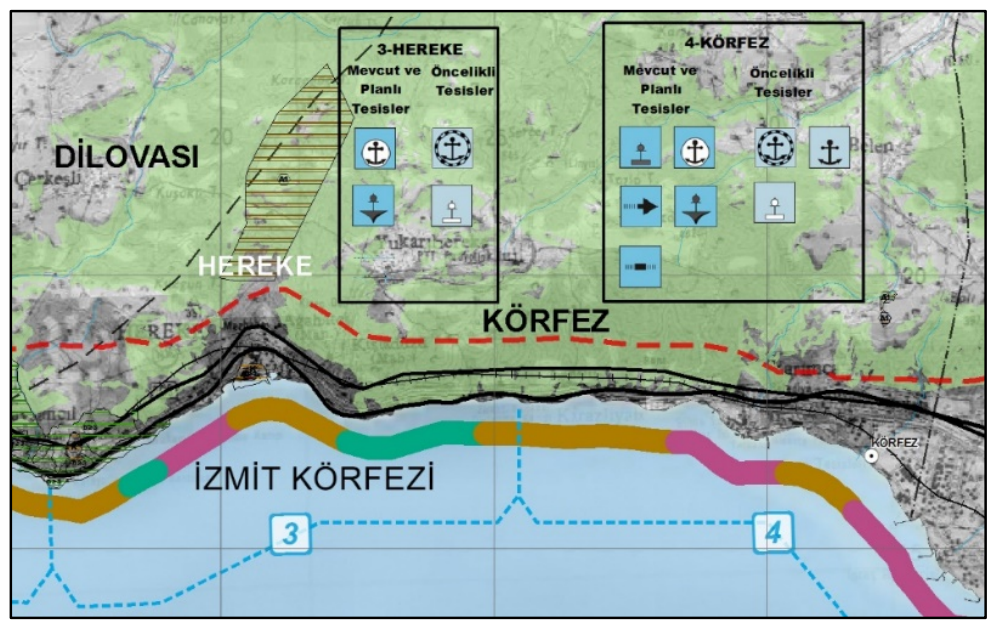

Şekil 6. İzmit Körfezi Bütünleşik Kıyı Alanları Planı Hereke Alt Bölgesi (Kaynak:

Mekânsal Planlama Genel Müdürlüğü, t.y.)

- Şekil 7'de görüldügüü gibi Gölcük ve Karamürsel ilçeleri çok yüksek ve yüksek riskli alanlar olarak tespit edilmiştir. Temel olarak yapılaşmaya uygunluk açısından potansiyel oluşturan ve ikincil konut istemi yoğunlaşan bir alan olan Gölcük-Karamürsel bölgesinde, nitelikli doğal alanlar ve önemli tarım alanları mutlaka korunmalıdır. Plan Açıklama Raporu'nda Gölcük ve Karamürsel bölgesi stratejik bölgeleme kararları kısmında geçen “...Rekreatif kullanımlara önem verilmesi... Yazlık konutların olduğu alanlarda kıyı kullanımını artırıcı kullanımların geliştirilmesi, özellikle geleneksel olarak kıyı kullanımları ve dinlence alanlarn ile ön plana çıkan kesimlerin bu niteliklerinin korunmasına ve yeniden kazanılmasına önem verilmesi..." gibi kararlar ile kentsel riskler içinde 
önemli bir yere sahip olan yapılaşma baskısı göz ardı edilmiştir. Spor tesisi, yat limanı yapılması öncelikli tesisler olarak tanımlanmış (Şekil 8) ve bu karalarla sezonluk nüfus artışı desteklenmiştir. Bu durumun doğal çevreye ve altyapıya ilişkin sorunlar yaratabileceği göz ardı edilmiştir. Dolayısıyla görece düşük riskli olan alanın risk derecesi de artacaktır.

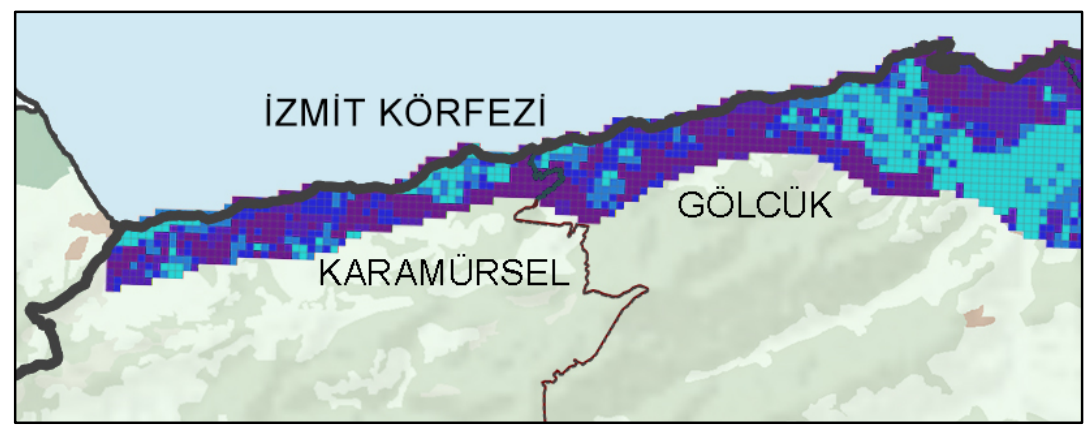

Şekil 7. Gölcük-Karamürsel Bölgesi Risk Derecelendirmesi

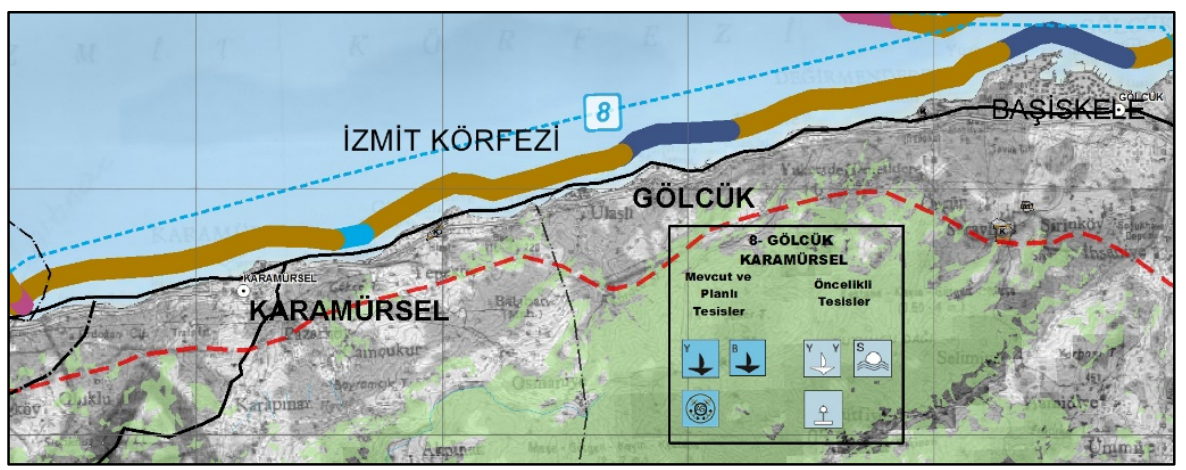

Şekil 8. İzmit Körfezi Bütünleşik Kıyı Alanları Planı Gölcük-Karamürsel Alt Bölgesi (Kaynak: Mekânsal Planlama Genel Müdürlüğü, t.y.)

\section{Tartışma ve Sonuç}

Temel olarak dirençlilik, alanda karşılaşılabilecek sorunların mevcut durumlarının detaylı olarak anlaşılması yoluyla gelecekte yaşanabilecek şoklara hazır olmayı ifade eder. Planlama bağlamında kentlerin dirençliliğini sağlamada strateji geliştirilmesi kadar önemli bir aşama da mevcut durumun doğru ve rasyonel bir biçimde tespit edilmesidir. Bu sebeple dirençli bir kent oluşturabilmek için öncelikle kentsel alanda gerçekleşen veya gerçekleşebilecek sosyal, sektörel, çevresel ve yönetsel riskler saptanmalıdır. Riskin tespit edilmesinde birçok farklı yöntem kullanılmakla birlikte önemli olan çalışma 
alanın doğal, çevresel ve demografik yapısına uygun olan analizleri ve değerlendirme biçimlerini seçerek uygulayabilmektir. Günümüzde geleneksel analiz yöntemleri ve değerlendirme biçimleriyle sınırlı kalan bir planlama yaklaşımı hâkimdir. Her kent ve kent parçası coğrafi yapısından ekonomisine kadar her açıdan özeldir. Bütün kentlerde aynı analizler ile benzer şekillerde üretilen plan kararlarının uygulanabilirliğinin düşük kalması, önemli maddi yük oluşmasına, planlara olan güvenin sarsılmasına ve kentin biricikliğinin kaybolmasına neden olabilmektedir. Yapılan analizlerin, afet tehlikesi hariç kentsel alanda oluşabilecek risklere ilişkin herhangi bir unsur içermemesi, geliştirilen plan kararlarının kentte yaşanacak krizleri görmezden gelmesi ile sonuçlanmaktadır.

Bu makale kapsamında Kocaeli Afet Müdahale Planı ve İzmit Körfezi Bütünleşik Kıyı Alanları Planı olmak üzere iki farklı nitelikte planlama çalışması yapılan risk analizleri ile ele alınmış ve değerlendirilmiştir. Her iki plan çalışmasında da yapılan analizler doğrultusunda mevcut çalışmalarda risk hesaplanması noktasında eksikliklerin olduğu ve çalışma kapsamında ele alınan bakış açısıyla geliştirilebilecek yönlerinin bulunduğu tespit edilmiştir.

Kocaeli Afet Müdahale Planı'nın İzmit özelinde değerlendirilmesi sonucunda, mevcuttaki durumu anlamak için sadece gerçekleşebilecek tehlikelere bakmanın yetmeyeceği; alanın riskini hesaplayıp buna göre kararlar almanın daha gerçekçi sonuçlara ulaştıracağı ortaya çıkmıştır. Sonuçta tehlike ne kadar yüksek olursa olsun, plan ile getirilebilecek zarar azaltma tedbiriyle, riskin azaltılabileceği ve olası can ve mal kayıplarının engellenebileceği görülmektedir.

İzmit Körfezi Bütünleşik Kıyı Alanları Planının değerlendirilmesi sonucunda ise bu planın riskleri, taşkın, heyelan ve deprem afetleri üzerinden genel bir perspektifle ele aldığ 1 ve geliştirilen stratejilerin "afet etkilerinden korunması" şeklinde ifade edilen yüzeysel bir içeriğe sahip olduğu görülmüştür. Burada önerilen biçimiyle bütünleşik kıyı alanları planlarının da dirençlilik bağlamında ele alınarak yapılacak analizlerle desteklenmesinin mümkün olabileceği gösterilmiştir. Böylece planda geliştirilen önerilerin ve önemli kıyı yapılarının, kente yaratacağı etkiler irdelenebilecek ve risk azaltımı sağlanabilecektir.

Planlama çalışmaları kapsamında oluşturulacak analizlere risk kavramının entegre edilmesi, kentin karşılaşabileceği krizlerle başa çıkabilmesine yönelik kararlar geliştirilmesini sağlayacaktır. Entegrasyonun sağlanabilmesi için riskin tanımından ortaya çıkan ve matematiksel bir ifadeyle belirtilen for- 
müller, alanın ve planın özelliklerine göre uyarlanarak mekânsallaştırılmalıdır. Bu yöntem ile planlama alanındaki riskler doğru ve rasyonel bir biçimde ortaya konulacağından plan kararlarının bu risklerle başa çıabilecek nitelikte olması beklenmektedir. 


\section{Extended Abstract}

\section{Two Studies for Identifying and Classifying Urban Risks in the Scope of Planning: The Case of Kocaeli}

\author{
Nurseli Şanlı \\ ORCID: 0000-0003-4336-590X \\ Sibel Ecemiş Kılıç \\ ORCID: 0000-0003-3928-8462
}

\author{
Fatma Nur Varol \\ ORCID: 0000-0003-2405-0603 \\ Mercan Efe Güney \\ ORCID: 0000-0001-8498-4796
}

The concept of urban resilience, which arises because of ensuring the sustainability of natural resources consumed today when a large part of the human population lives in cities, and allowing disaster and similar risks and economic, social and physical problems in cities to be solved and alleviated, has become an important concept to be addressed in the plan of all scales. Therefore, in order to create a resilient city, social, sectoral, environmental and administrative risks that may occur in the urban area should be identified first. However, today's planning approaches do not define the risks that may occur in urban areas except disasters for planning at all scales. To avoid cities from possible losses, risk and fragility need to be understood very well. Cities and all parts of them are different from the others about all features. Planning decisions produced in similar ways with the same analysis in all cities can reduce their applicability, undermine the confidence in the plans and lose the uniqueness of the city. The main objective of the study is to ensure urban resilience in the plans to be produced, to develop an applicable method to rate risks and levels, and to contribute to the spatial plans with the developed method. The developed method was implemented by integrated to two plans with different scales in Kocaeli Province. It is aimed to discuss the applicability of the method developed within the scope of the study to other plans and whether the solutions for the existing problems can be useful and sustained.

In both studies, Kocaeli province is preferred because of its location close to metropolises such as Istanbul, Bursa, Ankara, its advanced sectoral structure (logistics, industry, etc.), its role in the country's economy, and the effects which 
are still being felt of the 1999 Izmit Earthquake. At the same time Kocaeli, Turkey's most popular harbor area in which transportation with 34 active ports between the years 2011-2020, which has the Izmit Bay. For these reasons, the method developed within the context of resilience has been discussed in the urban planning and in the Kocaeli case. One of the applications of the method developed is for the Disaster Response Plan. As a type of plan aimed at being prepared for disasters in cities, the Disaster Response Plan is the most comprehensive plan for determining disaster risks in our country. Therefore, the method for risk assessment is discussed within the scope of disaster response plan. On the other hand, Izmit Bay is economically, socially, politically and politically valuable, and risk assessment and evaluation studies are important in the Izmit Bay Integrated Coastal Areas Plan covering Kocaeli coastal areas, which are exposured to risk due to natural and human impacts. In both studies, it was deemed necessary to identify and rate the risks in order to achieve resilience. The first study is in the Disaster Response Plan of Kocaeli Province; mathematically arising from the definition of risk in order to make risk determination; The Risk formula was used (Risk = [Danger $x$ Exposure $x$ Vulnerability] / Coping Capacity) (ISMEP, 2014). In the second study, formula which is mainly used in climate change action plans called Coastal Sensitivity used for the Izmit Bay Integrated Coastal Area Plan; (Vulnerability / Risk = [Exposure x Vulnerability] / Coping Capacity) (De Leon, 2006; Balica et al., 2009; Balica et al., 2012). Both formulas preferred within the scope of the study arise from the definition and components of risk. The data to be used in the selected application methods are diversified and differentiated by considering the type, scale and scope of the plans. These studies exemplify the use of concepts (danger, exposure, vulnerability or vulnerability, sensitivity, coping capacity or flexibility) that are also used as a data set category in risk and vulnerability detection and form the components of the risk formula with different data sets. Therefore, these studies show that risk can be defined in different ways according to the scope, scale and context of the application and can be integrated into the plan at any scale.

At the first study about Kocaeli Disaster Response Plan in Izmit, it is emerged that in order to understand the current situation, it is not enough to get the information about the dangers that may arise, but at the same time, calculating the risk and making decisions accordingly will lead to more reliable results. No matter how high the danger, it is seen that the risk can be reduced and possible loss of life and property can be prevented by the harm reduction measure that can be brought with the plan. 
At the second study about Izmit Bay Integrated Coastal Areas Plan, it was seen that this plan deals with the risks from a general perspective through floods, landslides and earthquake disasters and has a superficial content defined as "protection from disaster impacts" of the strategies developed. It has been shown that it is possible to support the plans of coastal areas integrated with the proposed formula to be applied in the context of resilience. Thus, the effects of the proposals developed in the plan and important coastal structures on the city can be examined and risk reduction can be achieved. Integrating the concept of risk into the analyses to be created within the scope of planning studies will enable the development of decisions to deal with the crises that the city may face. In order to achieve integration, the formulas arising from the definition of risk and specified in a mathematical description should be spatialized according to the characteristics of the field and the plan. With this method, it is expected that the planning decisions will be able to cope with these risks as the risks in the planning will be presented correctly and rationally.

\section{Kaynakça/References}

Balamir, M. (2007). Afet politikası, risk ve planlama. TMMOB Afet Sempozyumu, 5-7. https://www.spo.org.tr/genel/bizden_detay.php?kod=391\&tipi=58\&sube $=0$ adresinden erişilmiştir.

Balica, S. F. Douben, N. ve Wright, N. G. (2009). Flood vulnerability indices at varying spatial scales. Water science and technology, 60(10), 2571-2580.

Balica, S. F. Wright, N. G. ve Van der Meulen, F. (2012). A flood vulnerability index for coastal cities and its use in assessing climate change impacts. Natural hazards, 64(1), 73-105.

Çevre ve Şehircilik Bakanlığı, (t.y.). Kıyı alanlarının önemi. Erişim Adresi: https://mpgm.csb.gov.tr/kiyi-alanlarinin-onemi-i-84350

De León, V., ve Carlos, J. (2006). Vulnerability: a conceptional and methodological review. UNU-EHS.

Durgun E. (t.y.). Afete duyarlı planlama yaklaşımı ve yerbilimsel verilerin plana entegrasyonu. JMO haber bülteni. https://www.jmo.org.tr/resimler/ekler/ef21a66d373d628_ek.pdf?dergi=HABER\%20B\%DCLTEN\%DD adresinden erişilmiştir.

Görmüş, T., ve Ayat, B. (2020). Vulnerability assessment of Southwestern Black Sea. Journal of the Faculty of Engineering and Architecture of Gazi University, 35(2), 663-681.

Hester, R.E ve Harrison, R.M. (Eds.), (1998). Risk assessment and risk management. Cambridge: The Royal Society of Chemistry.

Holling, C. S. (1973). Resilience and stability of ecological systems. Annual review of ecology and systematics, 4(1), 1-23. 
İstanbul Valiliği, İstanbul Proje Koordinasyon Birimi (İSMEP) (2014). İstanbul afet müdahale plamı. İstanbul, Türkiye.

Kadığlu, M. (2011). Afet yönetimi beklenilmeyeni beklemek en kötüsünü yönetmek. T.C. Marmara Belediyeler Birliği Yayınları Yayın No:65. İstanbul.

Lebel, L., Anderies, J. M., Campbell, B., Folke, C., Hatfield-Dodds, S., Hughes, T. P., ve Wilson, J. (2006). Governance and the capacity to manage resilience in regional social-ecological systems. Ecology and Society, 11(1), 19.

Mekânsal Planlama Genel Müdürlüğ̈̈. (t.y.). İzmit Körfezi (Kocaeli - Yalova) Bütünleşik Kıyı Alanları Planı (KY-BKAP). https://mpgm.csb.gov.tr/izmit-korfezi-kocaeli--yalova-butunlesik-kiyi-alanlari-plani-ky-bkap-i-82284 adresinden erişilmiştir.

Töyli, J., Lorentz, H., Ojala, L., Wieland, A., ve Wallenburg, C. M. (2013). The influence of relational competencies on supply chain resilience: a relational view. International Journal of Physical Distribution \& Logistics Management, 300-320. 